\title{
Respiratory symptoms and ventilatory capacity in swine confinement workers
}

\author{
E Zuskin, Z Zagar, E Neil Schachter, J Mustajbegovic, J Kern
}

\begin{abstract}
A group of 59 workers ( 41 men and 18 women) employed in swine confinement areas was studied to assess the presence of acute and chronic respiratory symptoms and the prevalence of abnormalities in ventilatory function. A control group of 46 (31 men and 15 women) unexposed workers was studied for the prevalence of chronic respiratory symptoms. For both male and female swine confinement workers complaints of chronic cough, dyspnoea, and chest tightness were significantly more frequent than among control workers. Male workers also complained more of chronic phlegm. Male swine confinement workers who were smokers had significantly higher prevalences of chronic cough, chronic phlegm, and chronic bronchitis than male non-smoking swine confinement workers. The frequency of acute symptoms associated with the workshift was high among the swine confinement workers with more than half of the workers complaining of cough and dyspnoea associated with work. Significant acute across shift reductions in lung function occurred in swine confinement workers, being largest for FEF $_{25}$. All Monday preshift ventilatory capacity measurements in male confinement workers were significantly lower than predicted values; FVC and FEV 1 were found to be lower than predicted values for women. The data indicate that exposure in swine confinement buildings is associated with the development of acute and chronic respiratory symptoms and impairment of lung function. Smoking appears to aggravate these changes.
\end{abstract}

Organic dusts and their biologically active constituents are recognised as important factors in the

Andrija Stampar School of Public Health, Rockefellerova 4, 41000 Zagreb, Yugoslavia E Zuskin, Z Zagar, J Mustajbegovic, J Kern

The Mount Sinai School of Medicine, One Gustave L Levy Place, New York, NY 10029-6574, USA E Neil Schachter development of respiratory diseases in swine confinement buildings. In The Netherlands, pig farmers have far more health complaints than do other farmers. ${ }^{1}$ Among Dutch pig farmers a relation has been found between exposure in swine confinement buildings and effects on the respiratory system. ${ }^{2}$ Donham and Gustafsson ${ }^{3}$ reported that swine confinement workers developed high prevalences of acute respiratory symptoms as well as fever after exposure. The same authors divided respiratory symptoms into three major classifications-namely, acute respiratory symptoms, delayed symptoms, and acute toxic reactions. Donham et $\mathrm{al}^{4}$ found that swine confinement workers experienced a significantly higher prevalence of chronic bronchitis and wheezing than other farm workers. No significant abnormality in baseline pulmonary function was, however, documented. A high prevalence of chronic cough $(60 \%)$ and chronic phlegm $(40 \%)$ as well as changes in lung function were reported by Donham et al. ${ }^{5}$ Brouwer et $a l^{6}$ stated that average values of lung function for pig farmers were low when compared with normal values. Hog confinement farmers reported respiratory symptoms significantly more often than did controls, ${ }^{7}$ but lung function in that study did not differ between exposed and control farmers. Bongers $e t \mathrm{al}^{2}$ found that all measured pulmonary function values, except for FVC, were on average lower than expected for swine workers. The authors, however, did not find an association between duration of exposure and abnormalities of pulmonary function. Haglind and Rylander ${ }^{8}$ suggested that exposure to dust in swine confinement buildings may lead to respiratory impairment. These authors found, however, that characteristic changes in $\mathrm{FEV}_{1}$ over the work shift were generally absent. Dosman et $\mathrm{al}^{9}$ reported that swine producers had lower values for both forced vital capacity (FVC) and forced expiratory volume in one second $\left(\mathrm{FEV}_{1}\right)$ than did control subjects. This finding suggests a mixed restrictive and obstructive pattern of impairment among workers.

In the current investigation we studied the prevalence of respiratory symptoms and abnormalities of ventilatory function in a group of swine confinement workers employed on swine farms near Zagreb, Yugoslavia. 


\section{Subjects and methods} SUBJECTS

Fifty nine workers ( 41 men and 18 women) employed in swine confinement areas were studied. They represented $80 \%$ of all workers employed in these areas. The mean ages were 32 (range 19-54) for the men and 38 (range 22-57) for the women. The mean exposure in the swine confinement buildings for the men was eight (range 1-22) years; women were exposed on average for 10 (range 1-21) years. Among the men $26(63.4 \%)$ were smokers (mean 20 cigarettes daily). Among the women only five (27.7\%) smoked and they were light smokers. A control group of 31 men and 15 women employed in a fruit juice bottling company were also included in this study. These were matched by sex, age, and smoking habits but were not exposed to noxious agents in their workplace.

Swine confinement workers in this survey were employed in preparing animal food, feeding animals, cleaning confinement buildings, and breeding animals.

\section{RESPIRATORY SYMPTOMS}

Chronic respiratory symptoms were recorded using the British Medical Research Council Committee questionnaire on respiratory symptoms ${ }^{10}$ with additional questions on occupational asthma. ${ }^{11}$ In all workers a detailed occupational history and questions about their smoking habits were recorded. The following definitions were used:

Chronic cough or phlegm-cough, or phlegm production, or both for at least three months a year.

Chronic bronchitis-cough and phlegm for a minimum of three months a year and for not less than two successive years.

Dyspnoea grades-grade 3: shortness of breath when walking with other people at an ordinary pace on level ground; grade 4: shortness of breath when walking at their own pace on level ground.

Occupational asthma - recurring attacks of dyspnoea, chest tightness, and impairment of pulmonary function of the obstructive type diagnosed by physical examination and spirometric measurements during exposure to dust at or after work.

In all swine confinement workers, the presence of acute symptoms during a shift, such as cough, dyspnoea, chest tightness, irritation or dryness of the throat, secretion, dryness or bleeding of the nose, headache, and fever, were specifically recorded.

\section{VENTILATORY CAPACITY}

Ventilatory capacity was measured by recording maximum expiratory flow volume (MEFV) curves using a portable flow volume spirometer (Pneumoscreen, Jaeger, Germany). Measurements were performed on the first working day of the week (Monday) before $(6.00 \mathrm{am})$ and after $(2.00 \mathrm{pm})$ the workshift. The FVC, $\mathrm{FEV}_{1}$, and maximum expiratory flow rates at $50 \%\left(\mathrm{FEF}_{50}\right)$ and $25 \%$ $\left(\mathrm{FEF}_{25}\right)$ of the control vital capacity were measured on these curves. At least three MEFV curves were recorded and the best value was used as the result of the test. The measured Monday preshift values of ventilatory capacity were compared with the expected normal values of the Commission des Communautes Europeennes ${ }^{12}$ for FVC and $\mathrm{FEV}_{1}$ and of Cherniack and Raber $^{13}$ for $\mathrm{FEF}_{50}$ and $\mathrm{FEF}_{25}$.

\section{ENVIRONMENTAL MEASUREMENTS}

Airborne dust was sampled during an eight hour shift at the worksites of the examined workers. Casella personal samplers with Millipore field monitors and Millipore AA membrane filters were used to estimate total dust exposure.

Also, the concentrations of ammonia, hydrogen sulphide, carbon dioxide, and carbon monoxide were measured using Drager indicator tubes. These tubes were read immediately after sampling in the same locations in which dust and microbiological samples were taken.

The temperature and humidity were continuously registered in the stalls over an eight hour sampling period with a graphic thermohygrometer type 252 (Lambrecht Gottingen, Germany). Air flow was determined using a thermal anemometer (Wilh, Lambrecht KG, Gottingen, Germany).

Measurements of airborne bacteria were made in the breathing zone of the workers. Samples were collected with a bacteria sampler Mk2 (Casella, London). The air was sampled by vacuum pump with an intake flow of $30 \mathrm{l} / \mathrm{min}$. Total bacterial counts were measured on the surface of the blood nutrient agar and gram negative bacteria on the McConkey medium. The $\mathrm{pH}$ of the medium was $7 \cdot 0$. Samples were incubated for $24-48$ hours at $37^{\circ} \mathrm{C}$. Bacteria were counted as colony forming units in $1000 \mathrm{ml}$ of air. Total numbers of bacteria and gram negative bacteria were expressed as the numbers of colonies $/ \mathrm{m}^{3}$.

\section{Results \\ RESPIRATORY SYMPTOMS}

Table 1 presents the prevalence of chronic respiratory symptoms in swine confinement and control workers. Among the men, we found a statistically significant difference in the prevalence of all chronic respiratory symptoms except for chronic bronchitis. For the women we found significant differences in the prevalence of chronic cough, dyspnoea, and chest tightness between exposed and control workers. No cases of asthma were reported among exposed or control workers.

Table 2 indicates the prevalence of chronic respiratory symptoms in male swine confinement workers separately for smokers and non-smokers. 
Table 1 Prevalence of chronic respiratory symptoms in swine confinement workers and control workers

\begin{tabular}{|c|c|c|c|c|c|c|c|c|c|}
\hline \multirow[b]{2}{*}{ Group } & \multirow[b]{2}{*}{ No } & \multirow[b]{2}{*}{$\begin{array}{l}\text { Mean } \\
\operatorname{age}(y)\end{array}$} & \multirow{2}{*}{$\begin{array}{l}\text { Mean } \\
\text { exposure } \\
(y)\end{array}$} & \multicolumn{6}{|l|}{ No with } \\
\hline & & & & $\begin{array}{l}\text { Chronic } \\
\text { cough }\end{array}$ & $\begin{array}{l}\text { Chronic } \\
\text { phlegm }\end{array}$ & $\begin{array}{l}\text { Chronic } \\
\text { bronchitis }\end{array}$ & Asthma & Dyspnoea & $\begin{array}{l}\text { Chest } \\
\text { tightness }\end{array}$ \\
\hline \multicolumn{10}{|l|}{ Men: } \\
\hline Exposed & 41 & 32 & 8 & \multirow{2}{*}{$\begin{array}{c}17(41.5) \\
p<0.05 \\
6(19.4)\end{array}$} & \multirow{2}{*}{$\begin{array}{c}15(36.6) \\
p<0.05 \\
5(16.1)\end{array}$} & \multirow{2}{*}{$\begin{array}{l}13(31 \cdot 7) \\
\text { NS } \\
5(16 \cdot 1)\end{array}$} & \multirow{2}{*}{$\begin{array}{l}0(0) \\
\text { NS } \\
0(0)\end{array}$} & \multirow{2}{*}{$\begin{array}{l}9(21.9) \\
\mathrm{p}<0.01 \\
2(6.5)\end{array}$} & \multirow{2}{*}{$\begin{array}{l}9(21.9) \\
\mathrm{p}<0.01 \\
0(0)\end{array}$} \\
\hline Control & 31 & 36 & 7 & & & & & & \\
\hline \multicolumn{10}{|l|}{ Women: } \\
\hline Exposed & 18 & 38 & 10 & \multirow{2}{*}{$\begin{array}{c}9(50.0) \\
p_{1}<0.01 \\
1(6.7)\end{array}$} & \multirow{2}{*}{$\begin{array}{l}5(27 \cdot 8) \\
N S \\
1(6 \cdot 7)\end{array}$} & \multirow{2}{*}{$\begin{array}{l}3(16 \cdot 7) \\
\text { NS } \\
0(0)\end{array}$} & \multirow{2}{*}{$\begin{array}{l}0(0) \\
N S \\
0(0)\end{array}$} & \multirow{2}{*}{$\begin{array}{l}9(50.0) \\
\mathrm{p}<0.01 \\
1(6.7)\end{array}$} & \multirow{2}{*}{$\begin{array}{l}4(22.2) \\
p<0.05 \\
0(0)\end{array}$} \\
\hline Control & 15 & 35 & 8 & & & & & & \\
\hline
\end{tabular}

Non-significant $(p>0 \cdot 05)$. Percentages in parentheses.

Table 2 Prevalence of chronic respiratory symptoms according to smoking habit in male swine confinement workers

\begin{tabular}{llllllll}
\hline Group & No & $\begin{array}{l}\text { Chronic } \\
\text { cough }\end{array}$ & $\begin{array}{l}\text { Chronic } \\
\text { phlegm }\end{array}$ & $\begin{array}{l}\text { Chronic } \\
\text { bronchitis }\end{array}$ & Asthma & Dyspnoea & $\begin{array}{l}\text { Chest } \\
\text { tightness }\end{array}$ \\
\hline Smokers & 26 & $\begin{array}{l}16(61.5) \\
\mathrm{p}<0.01\end{array}$ & $\begin{array}{l}15(57 \cdot 7) \\
\mathrm{p}<0.01\end{array}$ & $\begin{array}{l}13(50 \cdot 0) \\
\mathrm{p}<0 \cdot 01\end{array}$ & $\begin{array}{l}0(0) \\
\text { NS }\end{array}$ & $\begin{array}{l}8(30 \cdot 8) \\
\text { NS }\end{array}$ & $\begin{array}{l}7(26.9) \\
\text { NS }\end{array}$ \\
Non-smokers & 15 & $1(6.7)$ & $0(0)$ & $0(0)$ & $0(0)$ & $1(6.7)$ & $2(13 \cdot 3)$ \\
\hline
\end{tabular}

NS $=$ Non-significant $(p>0 \cdot 05)$. Percentages in parentheses.

Smokers had a significantly higher prevalence of chronic cough, chronic phlegm, and chronic bronchitis than non-smokers $(p<0.01)$.

Table 3 presents the prevalence of acute symptoms during the workshift in swine confinement workers separately for male and female workers. The highest prevalence in both groups was found for cough, dry throat, throat irritation, and eye irritation. Among the women, many complained of headache. None of the studied workers complained of fever during or after the workshift.

VENTILATORY CAPACITY

Table 4 examines acute and chronic changes in ventilatory capacity. Data are presented as measured values and as a percentage change for FVC, $\mathrm{FEV}_{1}$, $\mathrm{FEF}_{50}$, and $\mathrm{FEF}_{25}$. The largest across shift reductions in the men were recorded for $\mathrm{FEF}_{25}(-12 \cdot 8 \%)$ with similar reductions for $\mathrm{FEF}_{25}(-9.4 \%)$ among the women. Comparison with predicted normal values showed significantly lower values for all preshift parameters in male workers and for $\mathrm{FVC}$ and $\mathrm{FEV}_{1}$ in female workers.

Table 5 presents the changes in ventilatory capacity in male swine confinement workers by smoking habit. Among smokers all ventilatory capacity tests were significantly lower than predicted normal values. Among non-smokers, the values were significantly lower for FVC and $\mathrm{FEV}_{1}$.

\section{ENVIRONMENTAL MEASUREMENTS}

Table 6 presents data on environmental measurements. All values were below the maximum allowed by Yugoslav standards except for relative humidity, which was somewhat higher.

\section{Discussion}

Our study confirms previous investigations that showed an increased prevalence of acute and chronic respiratory symptoms and abnormalities of lung function in workers employed in swine confinement buildings. Increased rates of chronic cough, dys-

Table 3 Prevalence of acute symptoms during work shift in swine confinement workers

\begin{tabular}{|c|c|c|c|c|c|c|c|c|c|c|}
\hline \multirow[b]{2}{*}{ Sex } & \multirow[b]{2}{*}{ No } & \multirow[b]{2}{*}{ Cough } & \multirow[b]{2}{*}{ Dyspnoea } & \multicolumn{2}{|l|}{ Throat } & \multirow{2}{*}{$\begin{array}{l}\text { Eye } \\
\text { irritation }\end{array}$} & \multicolumn{3}{|l|}{ Nose } & \multirow[b]{2}{*}{ Headache } \\
\hline & & & & Irritation & Dryness & & Secretion & Dryness & Bleeding & \\
\hline Men & 41 & $29(70 \cdot 7)$ & $23(56 \cdot 1)$ & $19(46 \cdot 3)$ & $27(65.9)$ & $19(46 \cdot 3)$ & $6(14 \cdot 6)$ & $12(29 \cdot 3)$ & $3(7 \cdot 3)$ & $4 \quad(9 \cdot 8)$ \\
\hline Women & 18 & $13(72 \cdot 2)$ & $11(61 \cdot 1)$ & $14(77 \cdot 8)$ & $13(72 \cdot 2)$ & $14(77 \cdot 8)$ & $6(33.3)$ & $6(33 \cdot 3)$ & $2(11 \cdot 1)$ & $9(50 \cdot 0)$ \\
\hline
\end{tabular}

Percentages in parentheses. 
Table 4 Acute and chronic changes of ventilatory capacity in swine confinement workers by sex

\begin{tabular}{|c|c|c|c|c|c|c|c|c|c|c|c|c|}
\hline \multirow{3}{*}{ Sex } & \multicolumn{3}{|l|}{$F V C$} & \multicolumn{3}{|l|}{$F E V_{1}$} & \multicolumn{3}{|l|}{$F E F_{50}$} & \multicolumn{3}{|l|}{$F E F_{25}$} \\
\hline & \multirow{2}{*}{$\begin{array}{l}\text { Before } \\
\text { shift } \\
l\end{array}$} & \multicolumn{2}{|c|}{$\begin{array}{l}\text { Difference } \\
\text { before-after shift }\end{array}$} & \multirow{2}{*}{$\begin{array}{l}\text { Before } \\
\text { shift } \\
l\end{array}$} & \multicolumn{2}{|c|}{$\begin{array}{l}\text { Difference } \\
\text { before-after shift }\end{array}$} & \multirow{2}{*}{$\begin{array}{l}\text { Before } \\
\text { shift } \\
l / s\end{array}$} & \multicolumn{2}{|c|}{$\begin{array}{l}\text { Difference } \\
\text { before-after shift }\end{array}$} & \multirow{2}{*}{$\begin{array}{l}\text { Before } \\
\text { shift } \\
l / s\end{array}$} & \multicolumn{2}{|c|}{$\begin{array}{l}\text { Difference } \\
\text { before-after shift }\end{array}$} \\
\hline & & $\%$ & $p$ & & $\%$ & $p$ & & $\%$ & $p$ & & $\%$ & $p$ \\
\hline $\begin{array}{l}\text { Men: } \\
\quad(n=41)\end{array}$ & \begin{tabular}{l}
\multicolumn{4}{c}{$\cdot 44$} \\
$(0 \cdot 72)$ \\
$\mathrm{p}<0 \cdot 001$ \\
$5 \cdot 33^{\star}$ \\
$(0 \cdot 76)$
\end{tabular} & $-5 \cdot 2$ & $\mathrm{p}<0.001$ & $\begin{array}{l}3.70 \\
(0.65) \\
\mathrm{p}<0.001 \\
4.23^{\star} \\
(0.63)\end{array}$ & $-3 \cdot 8$ & $p<0.001$ & $\begin{array}{l}5.55 \\
(1.36) \\
\mathrm{p}<0.05 \\
5.96^{\star} \\
(0.52)\end{array}$ & $-4 \cdot 1$ & $\mathrm{p}<0.001$ & $\begin{array}{l}2 \cdot 89 \\
(0.88) \\
\mathrm{p}<0.05 \\
3 \cdot 12^{\star} \\
(0.59)\end{array}$ & $-12 \cdot 8$ & $\mathrm{p}<0.001$ @ \\
\hline $\begin{array}{l}\text { Women: } \\
\qquad(n=18)\end{array}$ & $\begin{array}{l}3.32 \\
(0.61) \\
\mathrm{p}<0.001 \\
4.02^{\star} \\
(0.49)\end{array}$ & $-4 \cdot 8$ & $p<0.001$ & $\begin{array}{l}2.86 \\
(0.52) \\
\text { p }<0.01 \\
3.09^{\star} \\
(0.46)\end{array}$ & $-4 \cdot 5$ & $p<0.001$ & $\begin{array}{l}4 \cdot 57 \\
(0 \cdot 79) \\
\text { NS } \\
4 \cdot 71 \star \\
(0 \cdot 40)\end{array}$ & $-10 \cdot 1$ & $p<0.001$ & $\begin{array}{l}2.44 \\
(0.59) \\
\text { NS } \\
2.53^{\star} \\
(0.53)\end{array}$ & $-9 \cdot 4$ & $\mathrm{p}<0.001$ \\
\hline
\end{tabular}

$\star$ Predicted normal values. The data are presented as mean (SD). NS $=$ Non-significant $(p>0.05)$.

Table 5 Acute and chronic changes in ventilatory capacity in male swine confinement workers by smoking habit

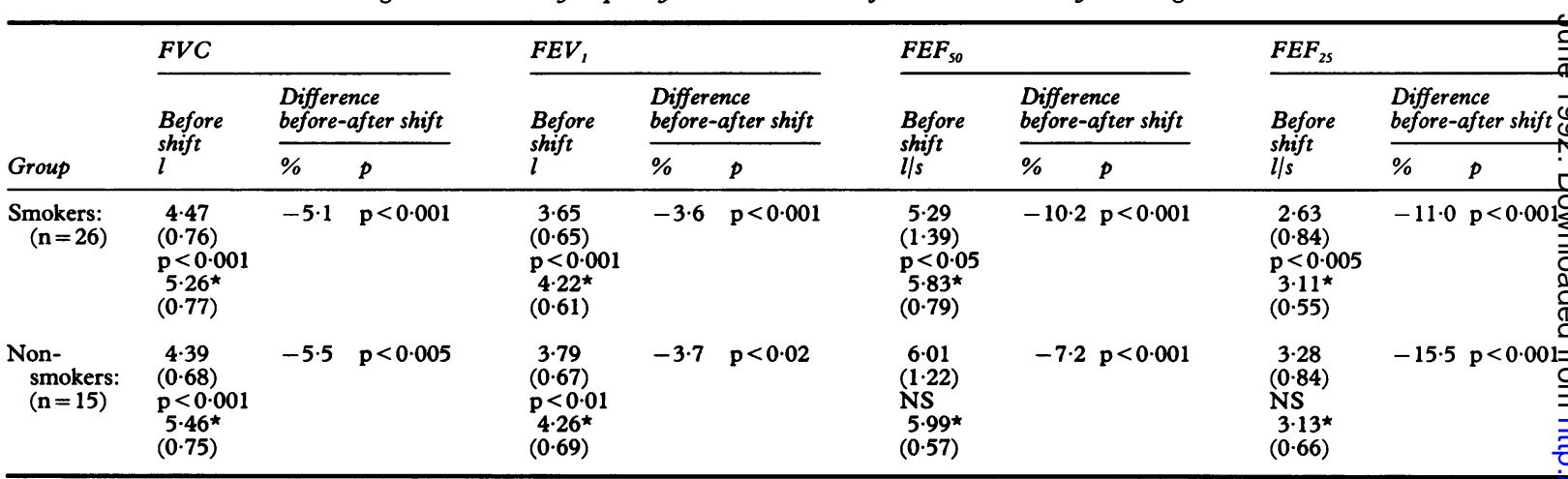

$\star$ Predicted values. The data are presented as mean $(S D)$. NS $=$ Non-significant $(p>0 \cdot 05)$.

pnoea, and chest tightness were noted in our male and our female swine confinement workers. The prevalence of dyspnoea among women was particularly high $(50.0 \%)$. These data are similar to our findings on animal food processing workers exposed to different components of animal food dust. ${ }^{14}$ Donham et al ${ }^{15}$ described an association between work in confinement areas and an increased rate of symptoms of bronchitis and respiratory diseases such as colds, chest illnesses, and pneumonia resulting in a significant loss of worktime. Previous clinical studies in the United States ${ }^{3-45-17}$ as well as the study by doPico $^{18}$ document febrile episodes suggestive of hypersensitivity syndrome occurring in swine workers.

In our study we did not find any workers with occupational asthma. The mean exposure of our workers varied from 8-10 years and the absence of occupational asthma might reflect a healthy worker effect. Harries and Cromwell ${ }^{19}$ have reported a case of occupational asthma in a 21 year old woman due to exposure to pig's urine. Recently Iversen et $a l^{20}$ found, in an epidemiological study of Danish farmers, that pig farming represented a significant risk for occupational asthma and chronic bronchitis (prevalence $10.9 \%-32.0 \%$ ). The authors found a strong association between age and most respiratory symptoms. The age of their workers varied from 3070 and reflected the number of years of exposure in this occupation. Recently Donham $e t a l,{ }^{21}$ in a five year prospective study, reported that swine confinement workers experience significant insult to the respiratory tract, manifest as inflammation typified by bronchitis and reactive airways. The mean exposure of their workers varied from 10-17 years. The same authors reported for the first time "Monday symptoms" similar to those seen with byssinosis. Donham et $\mathrm{al}^{22}$ also reported significantly higher frequencies of respiratory symptoms, more frequent colds and absence from work due to chest 
Table 6 Environmental variables in swine confinement buildings

\begin{tabular}{lll}
\hline & Measured values & $\begin{array}{l}\text { Maximum } \\
\text { allowable } \\
\text { values }\end{array}$ \\
\hline Aariable & $<5 \mathrm{ppm}$ & $50 \mathrm{ppm}$ \\
Ammonia & $<5 \mathrm{ppm}$ & $50 \mathrm{ppm}$ \\
Carbon monoxide & $<2000 \mathrm{ppm}$ & $5000 \mathrm{ppm}$ \\
Carbon dioxide & $<0.1 \mathrm{ppm}$ & $7 \mathrm{ppm}$ \\
Hydrogen sulphide & $<8 \mathrm{mg} / \mathrm{m}^{3}$ & $10 \mathrm{mg} / \mathrm{m}^{3}$ \\
Total dust & $<0.5 \mathrm{mg} / \mathrm{m}^{3}$ & $3 \mathrm{mg} / \mathrm{m}^{3}$ \\
Respirable dust & $18.4-25 \cdot 8^{\circ} \mathrm{C}$ & $10-25^{\circ} \mathrm{C}$ \\
Temperature & $73-86 \%$ & $40-70 \%$ \\
Relative humidity & $0 \cdot 06-0 \cdot 18 \mathrm{~m} / \mathrm{s}$ & $0.5 \mathrm{~m} / \mathrm{s}$ \\
Air flow (ventilation) & $0.9-1.5 \times 10^{5} \dagger$ & \\
Total bacteria & $0.9 \times 10^{3}-4.7 \times 10^{2} \dagger$ \\
Gram negative bacteria & \\
\hline
\end{tabular}

«Yugoslav Standards: National Commission on Environmental Health.

†Bacteria are presented as number of colonies per $\mathrm{m}^{3}$ air.

illness, and pneumonia in swine workers than in controls. In this study symptoms were related to the number of years and per cent of the day spent working with swine, to the level of respirable and total dust as well as the endotoxin content in total dust, and to the number of microbes in the air of the work environment.

In the present study small but statistically significant changes in ventilatory capacity in swine confinement workers over the workshift were seen. These were particularly pronounced for $\mathrm{FEF}_{25}$, suggesting that such changes in ventilatory capacity occur mostly in smaller airways. These changes are probably due to an interaction between the working environment and smoking.

Previous studies with workers exposed to the dust of coffee, soy bean, spices, or animal food showed similar significant acute reductions in $\mathrm{FEF}_{50}$ and $\mathrm{FEF}_{25}$ over workshifts; the changes in those groups were similar in non-smokers and smokers. ${ }^{1423-25}$ Acute decreases in flow rates among swine confinement workers were also found by Donham et al. ${ }^{4}$ Their data suggest a dose-response association between environmental exposure to carbon dioxide and hydrogen sulphide. Donham et al ${ }^{5}$ found correlations between across shift changes in pulmonary function and endotoxin concentrations and fermentative bacteria in swine confinement areas. Similar findings for dusts containing endotoxin, particularly cotton dust, have been reported. ${ }^{26-29}$ This dose response relation suggests that the biological composition of swine confinement area dust rather than the total amount of the dust itself may be important in causing airway diseases.

Preshift (baseline) tests of lung function have been used to characterise chronic effects of occupational exposure on lung function. Baseline FVC, $\mathrm{FEV}_{1}$, $\mathrm{FEF}_{50}$, and $\mathrm{FEF}_{25}$ in our male workers were significantly decreased with respect to predicted values.
Among female workers these differences were statistically significant only for FVC and $F E V_{1}$. Significantly lower measured values for flow rates in men are probably the result of concurrent smoking effects. Donham et al $^{30}$ suggested such an additive relation between smoking and exposure in the work environment on decline in lung function.

Airborne concentrations of contaminants in our confinement buildings were all within Yugoslav recommended values (table 6). Microclimatic conditions were normal except for relative humidity, which was higher than recommended. Donham and Popendorf ${ }^{31}$ found that carbon dioxide, hydrogen sulphide, carbon monoxide, and ammonia concentrations exceeded the respective threshold limit values in one or more of their units. Holness $e t a^{7}$ found that high total and respirable dust concentrations were associated with the use of floor (scatter) feeding, indoor feed grinding, and the use of high moisture corn feed. In our study the swine confinement areas had similar risk factors. Donham et $a l^{15}$ found that the two major constituents in the aerosols in swine confinement buildings were grain particles and dried swine fecal matter. Donham and Papendorf ${ }^{31}$ reported that buildings housing younger animals were more likely to have hazardous gas concentrations than buildings holding older animals. Clark et $a l^{32}$ found that airborne concentrations of total and gram negative bacteria in swine confinement units were as high or higher than those found in other environments, such as waste water treatment and cotton card rooms where microbiologically contaminated organic dusts were present. Altwood et al $^{33}$ reported that airborne dusts, endotoxin, bacteria, and ammonia are commonly found in high concentrations within swine confinement buildings and that these are present in concentrations at which health effects have been seen in other studies.

Donham et al $^{34}$ estimated that about 500000 people in the United States work in livestock confinement systems that use liquid manure storage. Hydrogen sulphide is a major toxic gas generated and agitation of the liquid manure is an important process in this work environment.

The prevalences of respiratory symptoms and abnormalities of lung function documented in this and other studies support the need for control programmes to protect workers in this industry. Current Yugoslav standards would appear to be inadequate for protecting workers. As indicated in related studies the complex air pollutants generated in this indoor environment need to be characterised and reduced. Also, workers need to be protected. Pre-employment medical examinations and medical surveillance should be considered, to protect susceptible workers from developing progressive disease. Tests of lung function should be performed before 
and after the workshift by recording $\mathrm{FEV}_{1}$ or MEFV curves. Such examinations would allow a better assessment of worker risk in swine confinement buildings and the identification of sensitive persons. In the case of progressive impairment of lung function or the development of respiratory symptoms, workers should be moved out of high risk areas. Persons with pre-existing lung disease should probably be advised to avoid working in swine confinement buildings that carry a risk of inducing acute or chronic respiratory disease.

This research was supported in part by Grant No JF 733 from the National Institutes of Health, Bethesda, MD USA; grant No RO1 OHO 2593-O1A1 from the National Institute of Occupational Safety and Health, Centers for Disease Control, Atlanta GA, USA; and by the Henry and Catherine Gaisman Fund, New York, NY, USA.

Requests for reprints to: Dr E Neil Schachter, The Mount Sinai School of Medicine, One Gustave L Levy Place, A24-251, New York, NY 10029, USA.

1 Willems HT, Verlinden F, Biersteker K. Work and health of the Dutch farmers. Tijdsche Soc Gezondheidsz 1984;62:21-7.

2 Bongers P, Hoothuija D, Remijn B, Brouwer R, Biersteker K. Lung function and respiratory symptoms in pig farmers. $\mathrm{Br} J$ Ind Med 1987;44:819-23.

3 Donham KJ, Gustafsson KE. Human occupational hazards from swine confinement. American Conference of Governmental Industrial Hygienists 1982;2:137-43.

4 Donham KJ, Zavala DC, Merchant JA. Respiratory symptoms and lung function among workers in swine confinement buildings: A cross-sectional epidemiological study. Arch Environ Health 1984;39:96-101.

5 Donham KJ, Scallon LJ, Popendorf WJ, Treuhaft MW, Roberts RC. Characterization of dusts collected from swine confinement buildings. Am Ind Hyg Assoc J 1986;47:404-10.

6 Brouwer R, Biersteker K, Bongers P, Houthuijs D. Respiratory symptoms, lung function, and IgG4 levels against pig antigens in a sample of dutch pig farmers. Am J Ind Med 1986;10: 283-5.

7 Holness DL, O'Glenis EL, Sass-Kortsak A, Pilger C, Nethercott JA. Respiratory effects and dust exposure in hog confinement farming. Am J Ind Med 1987;11:571-80.

8 Haglind $\mathrm{P}$, Rylander R. Occupational exposure and lung function measurements among workers in swine confinement buildings. J Occup Med 1987;29:904-7.

9 Dosman JA, Graham BL, Hall D, et al. Respiratory symptoms and alterations in pulmonary function tests in swine producers in Saskatchewan: Results of a survey of farmers. J Occup Med 1988;30:715-20.

10 Medical Research Council Committee on the Aetiology of Chronic Bronchitis. Standardized questionnaire on respiratory symptoms. BMJ 1960;2:1665.

11 World Health Organisation. Early detection of occupational disease. Geneva: WHO 1986:45-67.

12 Commission de Communautes Europeennes, CECA. Aide pour la pratique de l'examen de la function ventilatoire par la spirographie Luxembourgh: Collection d'Hygiene et de Medicine du Travail, 1971:No 11

13 Cherniack RM, Raber MB. Normal standards for ventilatory function using an automated wedge spirometer. Am Rev Respir Dis 1972;106:38-46.

14 Zuskin E, Mataija M, Pokrajac D, Schachter EN, Witek TJ. Respiratory function in animal food processing workers. $\mathrm{Am} \mathrm{J}$ Ind Med 1989;16:179-87.

15 Donham KJ, Haglind P, Peterson Y, Rylander R. Environmental and health studies in swine confinement buildings. $\mathrm{Am}$ $J$ Ind Med 1986;10:289-93.

16 Donham KJ, Knapp LW, Monson R, Gustafsson K. Acute toxic exposure to gases from liquid manure. J Occup Med 1982;24: 142-5.

17 Donham KJ, Popendorf WJ, Palmgren U, Larsson L. Characterization of dust collected from swine confinement buildings. Am J Ind Med 1986;10:294-7.

18 doPico GA. Report on diseases. Am J Ind Med 1986;10:261-5.

19 Harries MG, Cromwell $O$. Occupational asthma caused by allergy to pig's urine. $B M J 1982 ; 284: 867$.

20 Iversen M, Dahl R, Korsgaard J, Hallas T. Jensen EJ. Respiratory symptoms in Danish farmers: an epidemiological study of risk factors. Thorax 1988;43:827-77.

21 Donham KJ, Merchant JA, Lassise D, Popendorf WJ, Burmeister LF. Preventing respiratory disease in swine confinement workers: Intervention through applied epidemiology, education, and consultation. Am J Ind Med 1990; 18:241-61.

22 Donham KJ, Haglind P, Peterson Y, Rylander R, Belin I. Environmental and health studies of farm workers in Swedish swine confinement buildings. $\mathrm{Br} J$ Ind Med 1989;46:31-7.

23 Zuskin E, Valic F, Skuric Z. Respiratory function in coffee workers. Br J Ind Med 1979;36:117-22.

24 Zuskin E, Skuric Z, Kanceljak B, Pokrajac D, Schachter EN, Witek TJ. Respiratory symptoms and ventilatory capacity in soy bean workers. Am J Ind Med 1988;14:157-65.

25 Zuskin E, Skuric Z, Kanceljak B, Pokrajac D, Schachter EN, Witek TJ. Respiratory findings in spice factory workers. Arch Environ Health 1988;43:335-9.

26 Castellan RM, Olenchock SA, Hankinson JG, et al. Acute bronchoconstriction induced by cotton dust: dose-related responses to endotoxin and other dust factors. Ann Intern Med 1984;101:157-63.

27 Rylander R, Haglind P. Exposure of cotton workers in an experimental cardroom with reference to airborne endotoxins. Environ Health Perspect 1986;66:83-6.

28 Rylander R, Haglind $\mathbf{P}$, Lundholm $M$. Endotoxin in cotton dust and respiratory function decrement among cotton workers in an experimental cardroom. Am Rev Respir Dis 1985;131: 209-13.

29 Petsonk EL, Olenchock SA, Castellan RM, et al. Human ventilatory response to washed and unwashed cottons from different growing areas. Br J Ind Med 1986;43:182-7.

30 Donham KJ, Zavala DC, Merchant JA. Acute effects of the work environment on pulmonary function of swine confinement workers. Am J Ind Med 1984;5:367-75.

31 Donham KJ, Popendorf WJ. Ambient levels of selected gases inside swine confinement buildings. Am Ind Hyg Assoc J 1985;46:658-61.

32 Clark S, Rylander R, Larsson L. Airborne bacteria, endotoxin, and fungi in dust poultry and swine confinement buildings. Am Ind Hyg Assoc $J$ 1983;44:537-41.

33 Attwood P, Brouwer R, Ruigewaard P, et al. A study of the relationship between airborne contaminants and environmental factors in Dutch swine confinement buildings. Am Ind Hyg Assoc J 1987;48:745-75.

34 Donham KJ, Rubino $M$, Thedell TD, Kammermeyer J. Potential health hazards to agricultural workers in swine confinement buildings. J Occup Med 1977;19:383-7.

Accepted 7 October 1991. 